\title{
Vitamin D Supplementation
}

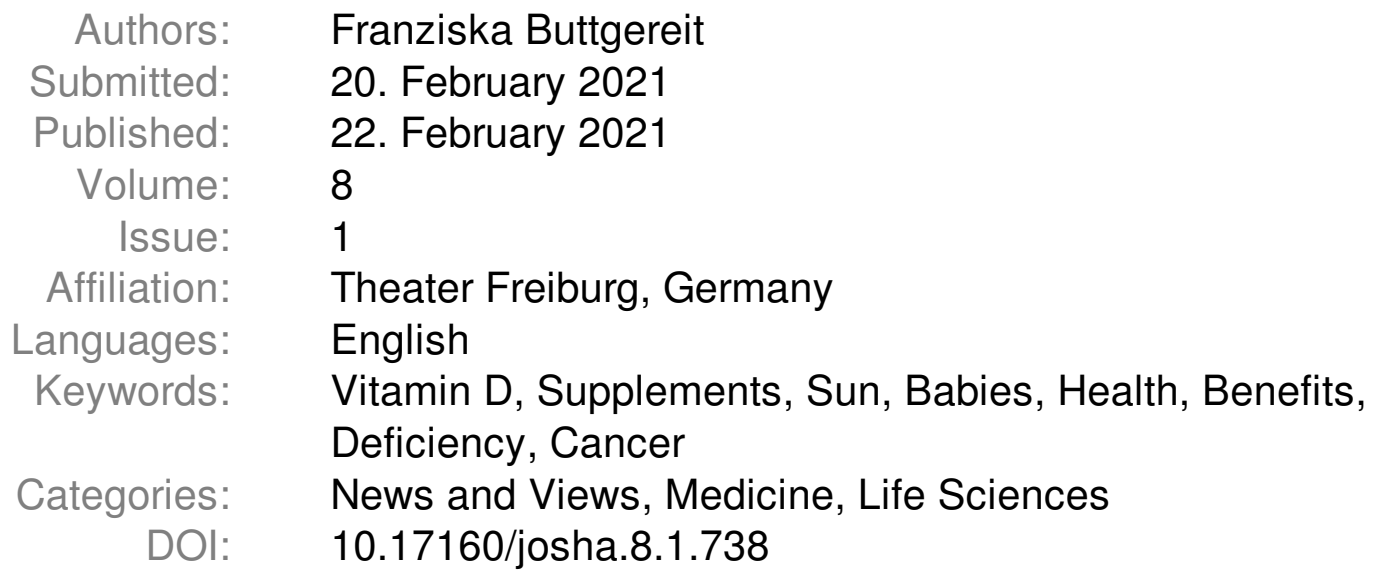

Abstract:

"We get little sunlight, especially in the winter months. However, vitamin D deficiency is not as widespread as supplement manufacturers would lead us to believe. According to statistics from the Robert Koch Institute, only two percent of adults suffer from vitamin D deficiency that requires treatment." 


\section{Vitamin-D Supplementation}

\section{Franziska Buttgereit}

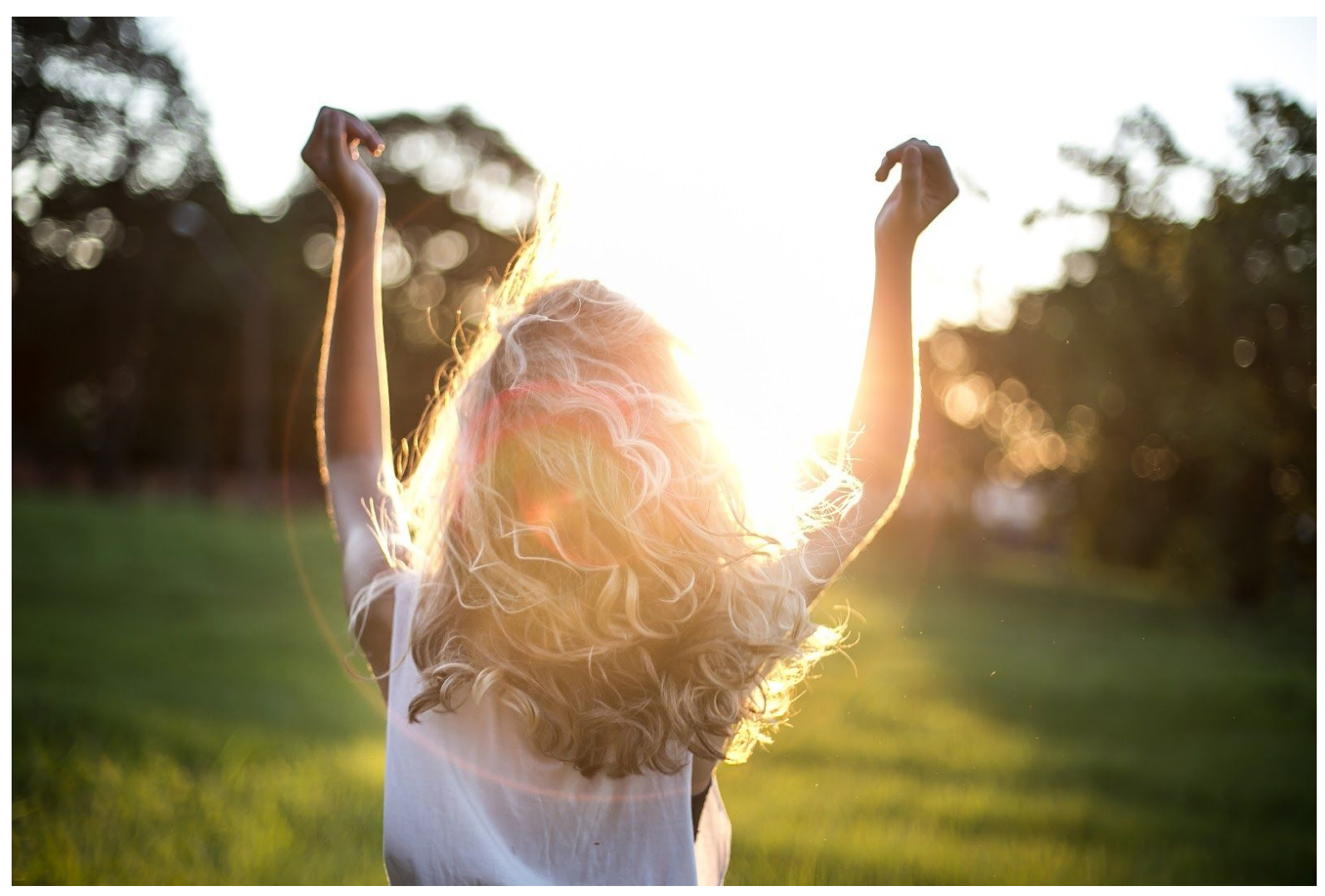

\section{Abstract}

"We get little sunlight, especially in the winter months. However, vitamin D deficiency is not as widespread as supplement manufacturers would lead us to believe. According to statistics from the Robert Koch Institute, only two percent of adults suffer from vitamin D deficiency that requires treatment." 
We get little sunlight, especially in the winter months. However, vitamin D deficiency is not as widespread as supplement manufacturers would lead us to believe. According to statistics from the Robert Koch Institute, only two percent of adults suffer from vitamin $\mathrm{D}$ deficiency that requires treatment.

A colorful assortment of vitamin D supplements can be found not only in pharmacies, but also on supermarket and drug store shelves. Internet business for the "sun vitamin" is flourishing. For some years now, vitamin D has been hyped in the media and in books, with some experts espousing that the vitamin may prevent cancer, diabetes, depression, and cardiovascular diseases. In addition, according to advertising of vitamin D supplement manufacturers, it would seem that almost every German citizen has a vitamin D deficiency.

One reason for the boom in the sun vitamin is likely to be found in the sales strategies of dietary supplement manufacturers who advertise their products as a miracle cure against numerous diseases.

Many consumers believe in the health benefits and safety of officially tested food supplements. In fact, these products are not tested for efficacy or safety by the authorities before they are launched.

The majority of the population is now adequately supplied with nutrients. Nevertheless, every third person in Germany takes dietary supplements according to a current Forsa survey taken on behalf of consumer advice centers. In this survey, it emerged that two misconceptions are particularly common:

\section{No positive effect}

$51 \%$ of the 1001 respondents consider food supplements to be beneficial for health. $35 \%$ consider them harmful. In fact, most powders and pills are simply unnecessary or ineffective for people who have a normal diet.

\section{Effectiveness and safety have not been tested}

$47 \%$ of those questioned believe that dietary supplements would be tested by the state for effectiveness and safety, while $44 \%$ were correct in assuming that this is not the case. Food supplements are legally defined in Germany as nutrients in concentrated form - often available in tablets or capsules - which are only intended to supplement one's general diet. There is no need for approval as is the case with pharmaceuticals, so they are not checked for their effectiveness and safety or for the veracity of their advertising. 
Thus, the idea that dietary supplements are generally safe and healthy is a fairy tale, however many consumers who buy such products trust them implicitly. According to the survey, $83 \%$ of buyers believe in a positive effect and $55 \%$ believe that the products have been government tested.

About a third of the approximately 1000 respondents said they had taken at least one food supplement in the last six months, with young adults up to the age of 29 being the most likely to take them. One's education does not seem to play a role.

More often than not, users of dietary supplements (83\%) purchase them in brick and mortar stores (i.e. supermarket, drugstore, pharmacy), while 13\% order them on the Internet. Roughly 3\% cited advertisements and/or sales letters as encouragement for buying supplements.

An overdose of vitamin D due to the body's own synthesis is not possible, however the situation is different when an external supplement is introduced. An overabundance of vitamin $D$ in the body leads to hypercalcemia, according to its functionality. If the elevated calcium serum level persists over a long enough period of time, clinical symptoms are expected, ranging from general fatigue and muscle weakness to gastrointestinal disorders, cardiac arrhythmias and nephropathies (kidney calcification or kidney stones).

Too high an amount of vitamin $D$ - through several food supplements at the same time, for example - can also lead to headaches, nausea, and loss of appetite (anorexia).

\section{No protection against cancer}

The findings on cancer are relatively clear. In a study with more than 25,000 subjects, carried out by researchers at Harvard Medical School in Boston, no evidence could be found that vitamin $D$ protects against tumors after five years. The result of a review from 2014, in which the data of 50,000 people were evaluated, also showed that it makes no difference for the incidence of cancer whether or not vitamin D supplements are taken. 


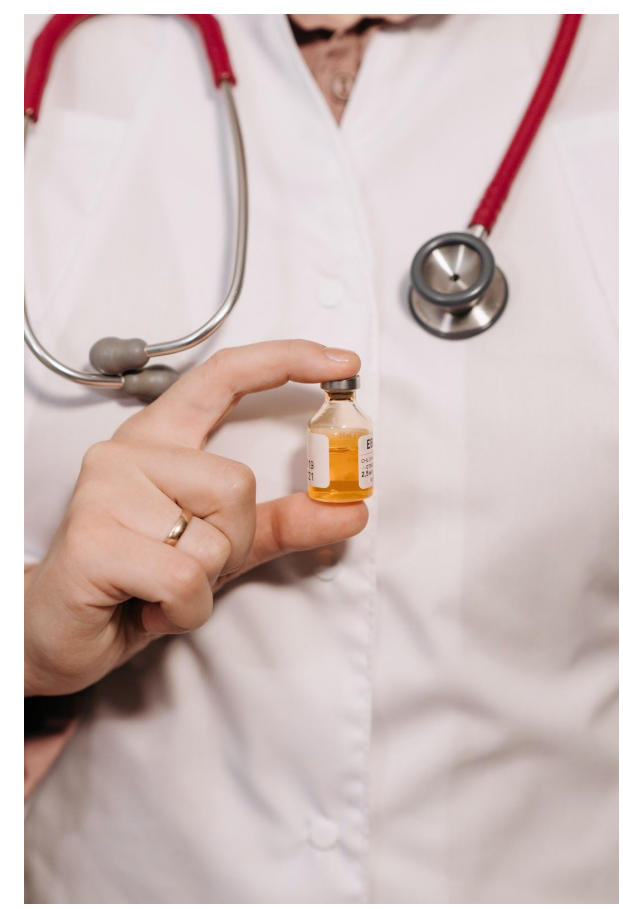

\section{When vitamin-D supplementation makes sense}

Without a doubt, vitamin $\mathrm{D}$ is an important nutrient for the body. The fat-soluble vitamin $\mathrm{D}$ acts like a hormone in the body and, in conjunction with parathyroid hormone and calcitonin, regulates the calcium and phosphate balance. The active form of vitamin D, calcitriol, promotes the absorption of calcium and phosphate from the small intestine, thus helping to strengthen teeth and bones. A severe deficiency can therefore lead to painful softening of the bones, known as osteomalacia in adults and rickets in children. The risk of osteoporosis also increases with a severe deficiency.

Diet can only account for 10 to 20 percent of one's daily vitamin $D$ requirement. The largest proportion is formed in the skin from a preliminary stage through the action of UVB radiation. From the age of 65 , the ability to form vitamin $D$ in the skin decreases significantly. Older people and people who rarely get out in the sun, such as nursing home residents, are among the risk groups. 
Babies get little vitamin D through their food in the first months of life, so it is advisable to consult with a pediatrician in order to prevent rickets. Those who do not belong to a risk group for a vitamin D deficiency and are unsure whether there is an undersupply in their bodies can have their vitamin $D$ level checked by a doctor. If there is a severe deficiency, vitamin $D$ can be prescribed as a medicinal product via prescription.

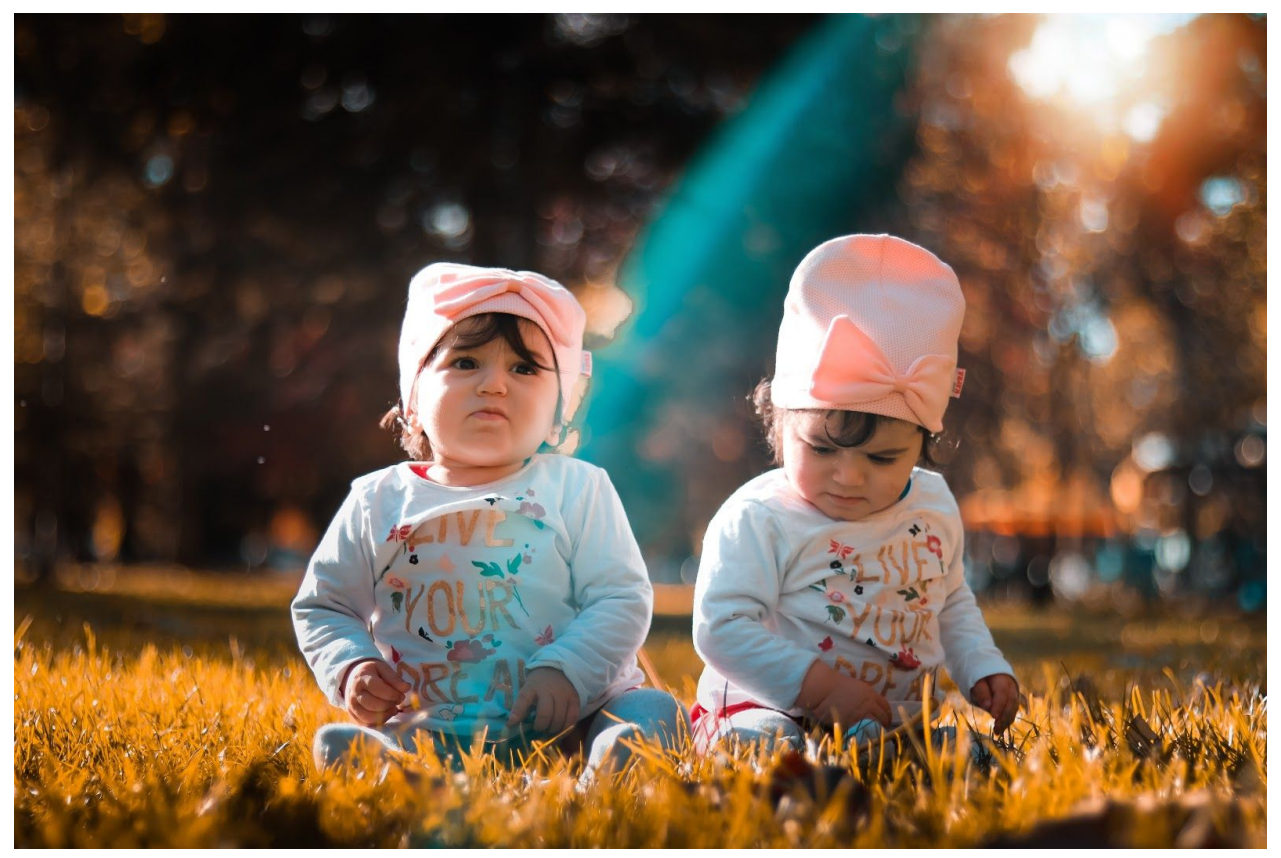

Here's the good news: the sun vitamin is not used up immediately in the body, but rather it is stored in fat and muscle tissue for a few months. That is usually enough to get one through the cold season, but how long the supply lasts varies from person to person. People who spend a lot of time outdoors therefore naturally have more in reserve than couch potatoes. 


\section{About the Author:}

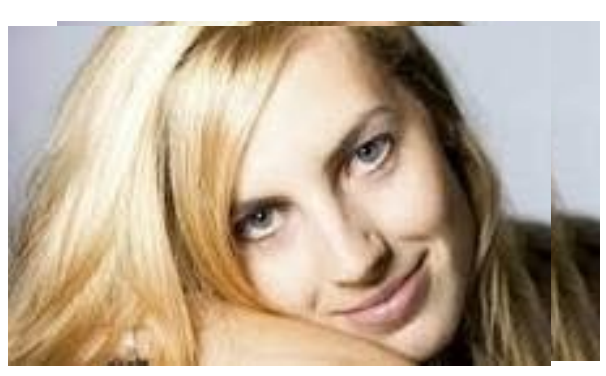

Franziska Buttgereit (Mezzosopranistin)

Franziska Buttgereit erhielt 1995 ihren ersten Blockflötenunterricht an der Jugendmusikschule Dreisamtal. 2000 wechselte sie in die Blockflötenklasse von Frau Prof. Agnes Dorwarth.

Von 2000-2010 gewann sie diverse Preise bei verschiedenen Wettbewerben, u.a dem Flötenwettbewerb in Bruchsal und „Jugend musiziert“ in verschiedenen Kategorien: Solo, Ensemble

und Alte Musik.

Darunter 2007 den 1. Bundespreis in der Kategorie Alte Musik sowie den Sonderpreis der Manfred Vetter-Stiftung als auch den 2. Preis für Alte Musik beim Händelwettbewerb in Karlsruhe.

Zudem nahm sie von 1998-2010 Querflötenunterricht bei Constanze von Bausznern und Susanne Hopfer.

2005 begann Franziska Buttgereit im Kinderchor als Ensemblemitglied des Stadtheaters Freiburg zu singen, was sie auch zu vielen kleinen solistischen Rollen in diversen Kinderopern brachte.

Den ersten Gesangsunterricht erhielt sie 2007 bei Frau Prof. Ingeborg Möller und Lini Gong.

Es folgten weitere Wettbewerbe und Preise im Fach Gesang, u. a. der 1. Bundespreis in der Kategorie Kunstlied Duo beim Wettbewerb „Jugend musiziert“ und der WESPE Sonderpreis des Bundesministeriums für Familie, Senioren, Frauen und Jugend für die „beste Interpretation eines Werkes einer Komponistin".

Diese Preise wiederum brachten Franziska nach Lübeck zu Meisterkursen bei Prof. Christiane Hampe und Michael Gehrke.

Seit 2010 ist sie Mitglied des Extrachores des Theater Freiburg und 1. Vorstand desselben seit 2017. 2015 begann sie ihr Studium für Gesang bei Prof. Christiane Libor an der Musikhochschule Schloss Gottesaue in Karlsruhe.

Bis heute folgen Kooperationen mit der Hochschule und dem Stadtheater Freiburg, was ihr u. a. zu einer kleinen Rolle in den Vorstellungen sowie der gleichnamigen DVD-Produktion „Cendrillon” von Jules Massenet verhalf.

Neben ihren Auftritten auf der Musiktheaterbühne widmet sich Franziska Buttgereit leidenschaftlich dem Oratorien- und Konzertrepertoire, womit sie regelmäßig als Solistin auftritt. 